\title{
Animal Reservoirs and Hosts for Emerging Alphacoronaviruses and Betacoronaviruses
}

\author{
Ria R. Ghai, Ann Carpenter, Amanda Y. Liew, Krystalyn B. Martin, Meghan K. Herring, Susan I. Gerber, \\ Aron J. Hall, Jonathan M. Sleeman, Sophie VonDobschuetz, Casey Barton Behravesh
}

The ongoing global pandemic caused by coronavirus disease has once again demonstrated the role of the family Coronaviridae in causing human disease outbreaks. Because severe acute respiratory syndrome coronavirus 2 was first detected in December 2019, information on its tropism, host range, and clinical manifestations in animals is limited. Given the limited information, data from other coronaviruses might be useful for informing scientific inquiry, risk assessment, and decision-making. We reviewed endemic and emerging infections of alphacoronaviruses and betacoronaviruses in wildlife, livestock, and companion animals and provide information on the receptor use, known hosts, and clinical signs associated with each host for 15 coronaviruses detected in humans and animals. This information can be used to guide implementation of a One Health approach that involves human health, animal health, environmental, and other relevant partners in developing strategies for preparedness, response, and control to current and future coronavirus disease threats.

C oronaviruses are a family of RNA viruses whose large genomes, propensity for mutation, and frequent recombination events have resulted in a diversity of strains and species that are capable of rapid adaptation to new hosts and ecologic environments (1). This viral plasticity has garnered widespread concern because of zoonotic potential and the consequences of new emergence events in both human and animal populations. The emergence of a new strain of severe acute respiratory syndrome coronavirus 2 (SARS-CoV-2), which causes coronavirus disease

\footnotetext{
Author affiliations: Centers for Disease Control and Prevention, Atlanta, Georgia, USA (R.R. Ghai, A. Carpenter, A.Y. Liew, K.B. Martin, M.K. Herring, S.I. Gerber, A.J. Hall, C. Barton Behravesh); Emory University, Atlanta (A.Y. Liew, K.B. Martin, M.K. Herring); US Geological Survey, Madison, Wisconsin, USA (J.M. Sleeman); Food and Agriculture Organization of the United Nations, Rome, Italy (S. VonDobschuetz)
}

DOI: https://doi.org/10.3201/eid2704.203945
(COVID-19) has once again demonstrated the role of the family Coronaviridae in causing human disease outbreaks. SARS-CoV-2, a novel betacoronavirus, was identified in human patients from Wuhan, China, during December 2019 and has resulted in a global pandemic, an unprecedented public health emergen$\mathrm{cy}$, and untold economic and societal repercussions worldwide. Similar to the 2002-2003 severe acute respiratory syndrome (SARS) epidemic, a live animal market where hundreds of animal species were sold is suspected to be associated with the emergence or early spread of COVID-19 in humans (2).

Although COVID-19 is novel in the breadth of the human outbreak, several pathogenic alphacoronaviruses and betacoronaviruses have shown similar patterns of emergence. As early as the 1930s, coronaviruses pathogenic to livestock, companion animals, and laboratory animals were identified (3). During the 1960s, 2 human coronaviruses, HCoV-229E and $\mathrm{HCoV-OC43,} \mathrm{were} \mathrm{detected} \mathrm{in} \mathrm{patients} \mathrm{who} \mathrm{had} \mathrm{com-}$ mon colds $(4,5)$. Although it is speculated that HCoVOC43 might also have emerged through a global pandemic in the late 1800s (6), the 2002-2003 SARS outbreak is the first known global epidemic caused by a coronavirus. The SARS epidemic triggered research within this viral family (3). This research led to detection of 2 new human coronaviruses, HCoV-NL63 and HCoV-HKU1 (7,8). HCoV-229E, HCoV-OC43, HCoVNL63, and HCoV-HKU1 are now accepted as globally endemic common cold species that are typically associated with mild-to-moderate respiratory illness. In 2012, the most deadly human coronavirus to date was detected in the Arabian Peninsula: Middle East respiratory syndrome coronavirus (MERS-CoV) (9). A cumulative body of research on these and other coronaviruses has shown that most alphacoronaviruses and betacoronaviruses infecting humans have come from animal hosts and that both historic patterns and coronavirus biology establish an urgent ongoing threat to human and animal health (10). 
Although coronaviruses are divided into 4 viral genera, namely alphacoronaviruses, betacoronaviruses, gammacoronaviruses, and deltacoronaviruses, we focus on alphacoronaviruses and betacoronaviruses because all known human coronaviruses are from these genera, and they may therefore pose an increased risk for causing future pandemics.

This review is intended to compile data to inform a One Health approach to combatting emerging alphacoronaviruses and betacoronaviruses. One Health is a collaborative, multisectoral, and transdisciplinary approach-working at the local, regional, national, and global levels - with the goal of achieving optimal health outcomes recognizing the interconnection between humans, animals, plants, and their shared environment (11). For example, in Qatar, a One Health approach for MERS-CoV prevention and control has been implemented since early in the outbreak, and is associated with improvements in coordination, joint outbreak response rates, and diagnostic capacity (12). Similarly, in the United States, establishment of the One Health Federal Interagency COVID-19 Coordination Group has been instrumental in ensuring an efficient and coordinated all-of-government response by creating a mechanism to communicate, share timely updates, and align messaging (13). More generally, the One Health approach is endorsed as an effective means of combatting zoonotic diseases internationally by the Tripartite international health organizations, consisting of the Food and Agriculture Organization of the United Nations, the World Health Organization, and the World Organisation for Animal Health (14).

As with other zoonotic diseases, effective implementation of a One Health approach for emerging coronaviruses requires an understanding of the transmission dynamics and human and animal hosts associated with the pathogen. Therefore, this review summarizes information from other coronavirus emergence events, which might be useful in identifying trends, establishing baselines, and informing decision-making by using a One Health approach around the current COVID-19 pandemic and future emerging coronavirus threats. Specifically, we provide information on the receptor used by each current or previously emerging coronavirus because tropism can help predict host susceptibility (Table 1) for all known hosts of each coronavirus and their host category (i.e., reservoir, intermediate, spillover, susceptible through experimental infection, or nonsusceptible through experimental infection) (Table 2, https://wwwnc.cdc.gov/EID/article/27/ 4/20-3945-T2.htm) and clinical signs associated with coronavirus infection (Table 3, https://wwwnc.cdc. gov/EID/article/27/4/20-3945-T3.htm)

\section{Emerging Coronaviruses and Wildlife}

More than $70 \%$ of zoonotic emerging infectious diseases in humans are caused by pathogens that have a wildlife origin (11). Several mammalian orders are now known to host coronaviruses, including carnivores, lagomorphs, nonhuman primates, ungulates and rodents (3). However, the attention has focused on Chiroptera (bats), which are hypothesized to be the origin host for all alphacoronaviruses and betacoronaviruses, and therefore all human coronaviruses (Table 2) $(1,3)$.

After rodents, bats are the second most diverse and abundant mammalian order, comprising $20 \%$ of all mammalian biodiversity worldwide. In the past 2 decades, research has intensified to determine why bats harbor more zoonotic diseases than other mammalian taxa, including pathogens that result in highconsequence infectious diseases, such as Ebola and Marburg filoviruses; Nipah and Hendra paramyxoviruses; and SARS-CoV, SARS-CoV-2, and MERS-CoV, emerging in humans (15). Behavioral and ecologic traits, such as their gregariousness, sympatry with mixed species assemblages in roosts, and long lifespan relative to size, have been suggested explanations for why bats are reservoirs to many viral pathogens (15). Physiologically, bats have comparatively high metabolic rates and typically do not show clinical signs after viral infection. Recently, it has also been shown that bats have several immune characteristics that are unique among mammals and that cumulatively dampen their antiviral responses (16). Those factors also probably contribute to their effectiveness as viral reservoirs.

Coronavirus richness and diversity detected in bats far exceeds those of other mammalian orders; $\geq 11$ of 18 chiropteran families across 6 continents have tested positive for $\geq 1$ coronavirus species (3). A study surveying the diversity of wildlife coronaviruses across global disease hotspots identified 100 distinct viruses, of which 91 were detected in bats (10). This study reported that patterns of coronavirus diversity mirrored bat diversity and evolutionary history, reinforcing the idea that bats are the predominant reservoir of zoonotic and emerging coronaviruses (10). On the basis of extrapolations made in the same study, Anthony et al. predicted that bats harbor $\approx 3,204$ coronaviruses, most of which remain undetected (10). Although much coronavirus diversity remains to be detected, several SARS-like coronaviruses have been detected already in bats, 
Table 1. Current or previously emerging coronaviruses*

\begin{tabular}{|c|c|c|c|}
\hline Pathogen (abbreviation) & Disease (abbreviation) & Viral genus & $\begin{array}{l}\text { Receptor (abbreviation) } \\
\text { [suspected] }\end{array}$ \\
\hline $\begin{array}{l}\text { Alphacoronavirus } 1 \text { (ACoV1); strain canine enteric } \\
\text { coronavirus (CCoV) }\end{array}$ & $\begin{array}{l}\text { Canine coronavirus infection } \\
\text { (CCoV) }\end{array}$ & Alphacoronavirus & $\begin{array}{l}\text { Aminopeptidase } \mathrm{N} \\
\text { (APN, CD13) }\end{array}$ \\
\hline $\begin{array}{l}\text { Alphacoronavirus } 1 \text { (ACoV1); strain feline } \\
\text { infectious peritonitis virus (FIPV) }\end{array}$ & $\begin{array}{l}\text { Feline infectious peritonitis virus } \\
\qquad(\mathrm{FIP})\end{array}$ & Alphacoronavirus & $\begin{array}{l}\text { Aminopeptidase N } \\
\text { (APN, CD13) }\end{array}$ \\
\hline Bat coronavirus HKU10 & NA & Alphacoronavirus & Unknown \\
\hline Ferret systemic coronavirus (FRSCV) & $\begin{array}{l}\text { Ferret systemic coronavirus } \\
\text { (FRSCV)-associated disease }\end{array}$ & Alphacoronavirus & Unknown \\
\hline Human coronavirus NL63 & Common cold & Alphacoronavirus & $\begin{array}{l}\text { Angiotensin-converting } \\
\text { enzyme } 2 \text { (ACE2) }\end{array}$ \\
\hline Human coronavirus 229E & Common cold & Alphacoronavirus & $\begin{array}{l}\text { Human aminopeptidase } \mathrm{N} \\
\text { (hAPN, CD13) }\end{array}$ \\
\hline Porcine epidemic diarrhea virus (PEDV) & $\begin{array}{l}\text { Porcine epidemic diarrhea } \\
\text { (PED) }\end{array}$ & Alphacoronavirus & $\begin{array}{l}\text { [Aminopeptidase N } \\
\text { (APN, CD13)] }\end{array}$ \\
\hline $\begin{array}{l}\text { Rhinolophus bat coronavirus HKU2; strain swine } \\
\text { acute diarrhea syndrome coronavirus (SADS- } \\
\text { CoV) }\end{array}$ & $\begin{array}{l}\text { Swine acute diarrhea syndrome } \\
\text { (SADS) }\end{array}$ & Alphacoronavirus & Unknown \\
\hline Betacoronavirus 1; strain bovine coronavirus & NA & Betacoronavirus & $\begin{array}{l}\text { Human leukocyte antigen } \\
\text { class I (HLA-1) }\end{array}$ \\
\hline $\begin{array}{l}\text { Betacoronavirus } 1 \text {; strain canine respiratory } \\
\text { coronavirus }\end{array}$ & $\begin{array}{c}\text { Canine infectious respiratory } \\
\text { disease (CIRD) }\end{array}$ & Betacoronavirus & $\begin{array}{l}\text { Human leukocyte antigen } \\
\text { class I (HLA-1) }\end{array}$ \\
\hline $\begin{array}{l}\text { Betacoronavirus } 1 \text {; strain human coronavirus } \\
\text { OC43 }\end{array}$ & Common cold & Betacoronavirus & $\begin{array}{l}\text { Human leukocyte antigen } \\
\text { class I (HLA-1) }\end{array}$ \\
\hline Human coronavirus HKU1 & Common cold & Betacoronavirus & $\begin{array}{l}\text { Human leukocyte antigen } \\
\text { class I (HLA-1) }\end{array}$ \\
\hline $\begin{array}{l}\text { Middle East respiratory syndrome coronavirus } \\
\text { (MERS-CoV) }\end{array}$ & $\begin{array}{l}\text { Middle East respiratory } \\
\text { syndrome (MERS) }\end{array}$ & Betacoronavirus & $\begin{array}{l}\text { Dipeptidyl peptidase } 4 \\
\text { (DPP4, CD26) }\end{array}$ \\
\hline $\begin{array}{l}\text { Severe acute respiratory syndrome coronavirus } \\
\text { (SARS-CoV) }\end{array}$ & $\begin{array}{l}\text { Severe acute respiratory } \\
\text { syndrome (SARS) }\end{array}$ & Betacoronavirus & $\begin{array}{l}\text { Angiotensin-converting } \\
\text { enzyme } 2 \text { (ACE2) }\end{array}$ \\
\hline $\begin{array}{l}\text { Severe acute respiratory syndrome coronavirus } 2 \\
\text { (SARS-CoV-2) }\end{array}$ & $\begin{array}{c}\text { Coronavirus disease } \\
\text { (COVID-19) }\end{array}$ & Betacoronavirus & $\begin{array}{l}\text { Angiotensin-converting } \\
\text { enzyme } 2 \text { (ACE2) }\end{array}$ \\
\hline
\end{tabular}

including viruses that use the same human cellular receptor molecule as SARS-CoV and SARS-CoV-2, and might therefore pose an increased risk for future emergence from bats to humans (17).

Despite the risks associated with bat-origin coronaviruses, bats play integral roles in ecosystems, including insect suppression through predation, prey for numerous predators, pollinators for economically and ecologically useful plants, and seed dispersal for countless tropical trees and shrubs (18). Therefore, mitigating the risks of future emergence events from bats would benefit from minimizing close interaction between humans and bats and other wildlife, by reducing or stopping wildlife sales at wet markets, wildlife hunting, and encroachment on wildlife habitat.

Although further research on bats might help to understand the origins of coronaviruses, other wildlife species are intermediate hosts for human emerging coronaviruses. Intermediate hosts might not only add complexity to coronavirus transmission dynamics, but might also amplify viral spillover to new hosts by closing gaps in interaction frequency between species, and by increasing transmissibility and/or infectiousness through viral adaptation (19). A canonical example is SARS-CoV, whose intermediate host is accepted to be palm civets (Table 2; Appendix, https: / / wwwnc.cdc.gov / EID/ article/27/4/203945-App1.pdf). In this instance, close interaction between humans and civets sold through wildlife markets probably facilitated transmission to humans, and passage and ongoing recombination in civet intermediate hosts is believed to have played a critical role in human receptor tropism $(19,20)$ (Table 1$)$.

Some wildlife species are at risk for human coronavirus spillover. Wild great apes, all species of which are endangered, are a taxonomic group vulnerable to spillover from humans, at least in part because they are our closest living relatives. Several documented respiratory outbreaks that resulted in clinical signs ranging from mild illness to death in chimpanzee and gorilla populations originated from a human source $(21,22)$. The human betacoronavirus HCoV-OC43 was reported as the causative agent of mild-to-moderate respiratory illness among wild chimpanzees in Côte D'Ivoire in late 2016 and early 2017 (Table 2; Appendix), suggesting the susceptibility of these chimpanzees to human coronaviruses. As the COVID-19 pandemic continues, there is concern that susceptible wildlife, such as great apes, might be exposed to the virus through human contact, resulting in a new host reservoir, which could pose a risk for perpetuating 
enzootic transmission and zoonotic transmission into recovering human populations.

Wildlife infections with SARS-CoV-2 have already occurred; the first natural infection of SARSCoV-2 in a wild animal, and the first confirmed animal cases in the United States, were in tigers $(n=5)$ and lions $(\mathrm{n}=3)$ at a zoo in New York, NY (Table 2; Appendix). Unlike most other asymptomatic animal cases reported previously, the large cats demonstrated respiratory signs that included coughing and wheezing but ultimately made a full recovery (Table 3). SARS-CoV-2 infection in wild felids in captivity highlights the complex interactions humans might have with wildlife, including the potential for human-to-wildlife transmission. Given these interlinkages, framing risk by using a One Health approach might more comprehensively address the socioeconomic and environmental drivers of disease emergence, leading to potentially novel, mutually beneficial solutions. For example, risks could be reduced by improving wildlife importation, trade and market regulations, and sanitary standards, which would not only protect public health and animal health but also result in positive wildlife conservation outcomes.

\section{Emerging Coronaviruses and Livestock}

Some coronaviruses naturally infect livestock and can have devastating economic consequences, such as swine acute diarrhea syndrome coronavirus (SADS-CoV), porcine epidemic diarrhea virus (PEDV), and betacoronavirus 1. Although recent studies suggest that pigs are not susceptible hosts for SARS-CoV-2 infection $(23,24)$, pigs are a common host for alphacoronaviruses and betacoronaviruses; 6 viral species cause disease (25) (Table 2). Of these species, the enteric alphacoronavirus PEDV is considered reemerging, and the enteric alphacoronavirus SADS-CoV (a strain of the Rhinolophus bat coronavirus HKU2) is considered emerging (25). Although PEDV was detected in China in the 1970s, a highly pathogenic variant caused considerable losses to the United States pork industry in 2013-2014 (26). SADS-CoV is highly pathogenic in swine and was detected in Guangdong Province in China during 2016-2017, causing the death of nearly 25,000 piglets (27) (Table 3). SADS-CoV emerged within $100 \mathrm{~km}$ of the accepted locale of the SARS index case, and like SARS-CoV and SARS-CoV-2, SADS-CoV is suspected to originate in horseshoe bats (Rhinolophus spp.) (Table 2; Appendix). However, unlike SARS$\mathrm{CoV}$ and SARS-CoV-2, SADS-CoV has not been detected outside China (25).
Among betacoronaviruses, a strain of betacoronavirus 1 also infects pigs (25). Porcine hemagglutinating encephalomyelitis virus has been circulating for decades and causes rapid death in piglets (25) (Table 3). Unlike other coronaviruses, betacoronavirus 1 is a unique species complex, in that its distinct strains are host-specific to a range of different species, including wild and domestic ungulates, rabbits, and canines $(19,28)$ (Table 2; Appendix). Perhaps the most well-studied strain of betacoronavirus 1 is bovine coronavirus (BCoV), which has a major economic role because it can be associated with a suite of clinical disease in calves and cattle, including calf diarrhea, winter dysentery, and respiratory infection (28) (Table 3). BCoV also infects several other livestock species, including horses, sheep, and camels $(19,28)$ (Table 2).

Livestock have also been intermediate hosts in the emergence of 3 human coronaviruses. An unknown ungulate species, speculated to be cattle, is accepted as the intermediate host of HCoV-OC43 $(6,29)$, a strain of betacoronavirus 1 (Table 2). On the basis of molecular clock calculations, $\mathrm{HCoV}-\mathrm{OC} 43$ is predicted to have jumped from livestock to humans around 1890, a timeframe coincident with pandemics of respiratory disease in cattle (which resulted in widespread culling) and humans (although this outbreak is historically attributed to influenza) (6). Dromedary camels are accepted as established hosts of MERS-CoV and are believed to be associated with the emergence of HCoV-229E in humans on the basis of closely related viruses found in camelids (Table 2; Appendix). Dromedary camels inhabit the Middle East and northern Africa and comprise $90 \%$ of extant camels on earth. In much of their range, dromedaries are a major livestock species that are used as racing and working animals, as well as for their milk, meat, and hides.

Livestock can also be spillover hosts of human coronavirus infection. After the 2002-2003 SARS outbreak, a study conducted on farms in Xiqing County, China, tested livestock (pigs, cattle, chickens, and ducks) and companion animals (dogs and cats), leading to detection of 1 pig that was positive for SARS-CoV by antibody test and reverse transcription PCR (30) (Table 2). A larger and more complex series of livestock outbreaks of SARSCoV-2 has been unfolding since April 2020. Mink farms across Europe and North America have reported outbreaks of SARS-CoV-2 (Tables 2, 3). In most outbreaks, farmed mink were suspected to be initially infected by COVID-19-positive farm employees $(31,32)$. Findings from the Netherlands have 
also identified instances of spillback from mink to humans through ongoing investigations (33). National surveillance and control efforts have been implemented in several countries, many of which have subsequently identified other SARS-CoV-2positive species living on or nearby mink farms, including cats, dogs, and escaped or wild mink (32). Several countries have implemented mandatory reporting of any virus-positive animals and depopulation or quarantine of affected farms (32). In Europe, several million mink have been culled, and a moratorium has been placed on the mink industry in some countries; such early and coordinated One Health actions are needed to prevent bidirectional transmission of zoonotic diseases (32).

\section{Emerging Coronaviruses and Companion Animals}

Companion animals are members of many households and can improve the physical and mental wellbeing of their owners (34). In the United States, $\approx 71.5$ million households (57\%) own $\geq 1$ companion animal (35). Among households with companion animals, dogs $(67 \%)$ and cats $(44 \%)$ are the most commonly owned (35). Despite the many benefits of pet ownership, close interactions with pets pose risks for zoonotic disease transmission (34). Zoonotic diseases that are spread between humans and companion animals include rabies, salmonellosis, campylobacteriosis, and hookworm $(34,36,37)$. Companion animals are estimated to be a source of $>70$ human diseases (38), and the burden of zoonotic diseases attributed to interactions with companion animals is substantial. For example, rabies kills $\approx 59,000$ persons per year globally, and $99 \%$ of human rabies cases originate from rabid dogs (37).

Several common coronaviruses have been detected in companion animals, although none of the coronaviruses that are endemic to companion animal populations are zoonotic. One of the most common respiratory diseases in dogs is canine infectious respiratory disease, or kennel cough, which typically causes cough and nasal discharge in puppies and dogs $(39,40)$. Although kennel cough can be caused by several pathogens, most frequently the bacterium Bordetella bronchiseptica, canine respiratory coronavirus $(\mathrm{CRCoV})$ is a contributing pathogen to this syndrome $(39,41)$ (Table 1$)$. CRCoV is believed to originate from $\mathrm{BCoV}$ through a common ancestor, host variant, or a host species shift and is therefore considered a strain of betacoronavirus $1(39,41)$. Regardless of how $\mathrm{CRCoV}$ and $\mathrm{BCoV}$ are genetically related, experimental studies have shown that dogs challenged with $\mathrm{BCoV}$ can become infected and transmit the virus to other dogs, although they do not exhibit clinical signs of disease (Tables 2, 3; Appendix).

Canine enteric coronavirus $(\mathrm{CCoV})$ is an alphacoronavirus often associated with mild enteritis in puppies and dogs, especially in group housing situations (42). However, during 2005, a novel, highly pathogenic variant strain of CCoV-II, CB/05, was identified (43) (Table 2). This new variant is now pantropic, and results in a mortality rate up to $100 \%$ in isolated outbreaks in puppies (43) (Table 3). Because of its increased pathogenicity and changes in tissue tropism, $\mathrm{CCoV}$ is considered an emerging pathogen (42).

Although CCoV is generally considered to be specific to dogs, cats experimentally challenged with the virus can be infected with $\mathrm{CCoV}$ and mount an anamnestic response to further exposure, although they do not develop clinical signs of illness (Table 3; Appendix). In addition, although there are 2 serotypes of feline coronavirus (FCoV), FCoV type I and $\mathrm{FCoV}$ type II, type II is hypothesized to have originated from a recombination event between FCoV type I and $\mathrm{CCoV}$, which suggests co-infections of coronaviruses among companion animals might yield opportunity for emergence of new disease (44).

Companion animals might also act as spillover hosts for human coronaviruses. A study after the 2002-2003 SARS outbreak showed that pet cats living in a Hong Kong, China, apartment complex were naturally infected with SARS during the epidemic (45). After the epidemic, challenge experiments in cats and ferrets found that both species could be experimentally infected and transmit the infection to immunologically naive animals of the same species they were housed with (45) (Table 2). In this experiment, cats did not show clinical signs of illness, although ferrets became lethargic, showed development of conjunctivitis, and died on days 16 and 21 postinfection. However, unlike human cases, there was no evidence that SARS-CoV-associated pneumonia was a cause of death (Table 3). Rather, the main findings in deceased ferrets were marked hepatic lipidosis and emaciation (45).

Companion animals, specifically dogs and cats, are among the most commonly infected groups of animals in the ongoing COVID-19 pandemic. Natural cases of suspected human-to-animal transmission have been confirmed in dogs and cats from several countries, and the earliest reports date back to March 2020 in Hong Kong (32). As of January 2021, there are $\approx 100$ confirmed cases of SARS-CoV-2 infections in dogs and cats in the United States; most of those 
cases resulted from exposure to owners who had COVID-19 (46). Experimental challenge studies additionally suggest that similar to SARS-CoV, several companion animals, including cats, ferrets, and golden hamsters, are all susceptible to SARS-CoV-2 infection under laboratory conditions (Table 2; Appendix). Furthermore, studies in cats, hamsters, and ferrets showed that they are capable of direct and indirect transmission to healthy animals of the same species in experimental settings $(23,24,47,48)$, which underscores the need for infection prevention and control practices for humans and companion animals (49).

The global prevalence of companion animal ownership underscores the need for better understanding of pathogens, such as coronaviruses, that can infect pets. Because companion animals harbor endemic coronaviruses and might also be at risk for spillover for some human zoonotic coronaviruses, there is potential for coronavirus recombination events and new viral emergence to occur within these hosts. Therefore, ensuring that persons understand how to safely interact with their companion animals is essential for ensuring that persons and companion animals stay healthy while also protecting animal welfare.

\section{Conclusions}

A considerable number of mammalian species, including wildlife, livestock, and companion animals, are susceptible to infection with alphacoronaviruses and betacoronaviruses. The propensity of alphacoronaviruses and betacoronaviruses to jump to new hosts, coupled with their relatively large host ranges, suggests that a One Health approach could be used to develop strategies to mitigate the effects of current and future coronavirus emergence events. During the COVID-19 pandemic, One Health collaboration between public health and veterinary sectors has already bolstered critical healthcare resources and infrastructure, leading to improvements in diagnostic testing capacity and human resource availability (50). In the United States, the One Health Federal Interagency COVID-19 Coordination Group has developed risk communication and messaging for companion animals, livestock, and wildlife and has been instrumental in coordinating joint outbreak response and diagnostic testing in animals. As these examples highlight, integration of the One Health approach into preparedness planning, joint epidemiologic investigations, surveillance, laboratory diagnostics, risk assessment, and field research is not only beneficial but a useful approach to safeguard the health, welfare and safety of humans, animals, and their shared environment.

\section{Acknowledgments}

We thank members of the COVID-19 One Health Working

Group of the Centers for Disease Control and Prevention, the One Health Federal Interagency Coordination Group, and state and local partners for providing valuable contributions and insights for this manuscript.

The opinions expressed by authors contributing to this journal do not necessarily reflect the opinions of the Centers for Disease Control and Prevention, Emory University, or the Food and Agriculture Organization of the United Nations, but do represent the views of the US Geological Survey.

\section{About the Author}

Dr. Ghai is an associate service fellow in the One Health Office, National Center for Emerging and Zoonotic Infectious Diseases, Centers for Disease Control and Prevention, Atlanta, GA. Her primary research interests include One Health, disease ecology, and zoonotic diseases.

\section{References}

1. Woo PC, Lau SK, Huang Y, Yuen K-Y. Coronavirus diversity, phylogeny and interspecies jumping. Exp Biol Med (Maywood). 2009;234:1117-27. https:/ / doi.org/ 10.3181/0903-MR-94

2. Huang C, Wang Y, Li X, Ren L, Zhao J, Hu Y, et al. Clinical features of patients infected with 2019 novel coronavirus in Wuhan, China. Lancet. 2020;395:497-506. https:/ / doi.org/ 10.1016/S0140-6736(20)30183-5

3. Drexler JF, Corman VM, Drosten C. Ecology, evolution and classification of bat coronaviruses in the aftermath of SARS. Antiviral Res. 2014;101:45-56. https:/ / doi.org/10.1016/ j.antiviral.2013.10.013

4. Hamre D, Procknow JJ. A new virus isolated from the human respiratory tract. Proc Soc Exp Biol Med. 1966;121:190-3. https:/ / doi.org/10.3181/00379727-121-30734

5. McIntosh K, Dees JH, Becker WB, Kapikian AZ, Chanock RM. Recovery in tracheal organ cultures of novel viruses from patients with respiratory disease. Proc Natl Acad Sci U S A. 1967;57:933-40. https:/ / doi.org/10.1073/pnas.57.4.933

6. Vijgen L, Keyaerts E, Moës E, Thoelen I, Wollants E, Lemey $\mathrm{P}$, et al. Complete genomic sequence of human coronavirus OC43: molecular clock analysis suggests a relatively recent zoonotic coronavirus transmission event. J Virol. 2005;79:1595-604. https:/ / doi.org/10.1128/ JVI.79.3.1595-1604.2005

7. van der Hoek L, Pyrc K, Jebbink MF, Vermeulen-Oost W, Berkhout RJ, Wolthers KC, et al. Identification of a new human coronavirus. Nat Med. 2004;10:368-73. https://doi.org/10.1038/nm1024

8. Woo PC, Lau SK, Chu CM, Chan KH, Tsoi HW, Huang Y, et al. Characterization and complete genome sequence of a novel coronavirus, coronavirus HKU1, from patients with pneumonia. J Virol. 2005;79:884-95. https:/ / doi.org/ 10.1128/JVI.79.2.884-895.2005

9. Zaki AM, van Boheemen S, Bestebroer TM, Osterhaus AD, Fouchier R. Isolation of a novel coronavirus from a man with pneumonia in Saudi Arabia. N Engl J Med. 2012;367:1814-20. https://doi.org/10.1056/NEJMoa1211721 
10. Anthony SJ, Johnson CK, Greig DJ, Kramer S, Che X, Wells H, et al.; PREDICT Consortium. Global patterns in coronavirus diversity. Virus Evol. 2017;3:vex012. https://doi.org/10.1093/ve/vex012

11. Centers for Disease Control and Prevention. One Health. 2020 [cited 2020 Jul 15]. https:// www.cdc.gov/onehealth/ index.html

12. Farag E, Nour M, Islam MM, Mustafa A, Khalid M, Sikkema RS, et al. Qatar experience on One Health approach for Middle East respiratory syndrome coronavirus, 2012-2017: a viewpoint. One Health. 2019;7:100090. https://doi.org/10.1016/j.onehlt.2019.100090

13. Newman A, Smith D, Ghai RR, Wallace RM, Torchetti MK, Loiacono C, et al. First reported cases of SARS-CoV-2 infection in companion animals - New York, March-April 2020. MMWR Morb Mortal Wkly Rep. 2020;69:710-3. https:/ / doi.org/10.15585/mmwr.mm6923e3

14. World Health Organization, Food and Agriculture Organization of the United Nations, World Organisation for Animal Health. Taking a multisectoral, One Health approach: a tripartite guide to addressing zoonotic diseases in countries. Geneva: The Organization; 2019.

15. Luis AD, Hayman DT, O'Shea TJ, Cryan PM, Gilbert AT, Pulliam JR, et al. A comparison of bats and rodents as reservoirs of zoonotic viruses: are bats special? Proc Biol Sci. 2013;280:20122753. https:/ / doi.org/10.1098/ rspb.2012.2753

16. Banerjee A, Baker ML, Kulcsar K, Misra V, Plowright R, Mossman K. Novel insights into immune systems of bats. Front Immunol. 2020;11:26. https:/ / doi.org/10.3389/ fimmu.2020.00026

17. Ge X-Y, Li J-L, Yang X-L, Chmura AA, Zhu G, Epstein JH, et al. Isolation and characterization of a bat SARS-like coronavirus that uses the ACE2 receptor. Nature. 2013;503:535-8. https:// doi.org/10.1038/nature12711

18. Kasso M, Mundanthra B. Ecological and economic importance of bats (order Chiroptera). Int Sch Res Notices. 2013;2013:187415 [cited 2021 Jan 22]. https:/ / www.hindawi. com/journals/isrn/2013/187415

19. Corman VM, Muth D, Niemeyer D, Drosten C. Hosts and sources of endemic human coronaviruses. In: Kielian M, Mettenleiter TC, Roossinck MJ, editors. Advances in Virus Research. New York: Academic Press; 2018. p. 163-88.

20. Song H-D, Tu C-C, Zhang G-W, Wang S-Y, Zheng K, Lei L-C, et al. Cross-host evolution of severe acute respiratory syndrome coronavirus in palm civet and human. Proc Natl Acad Sci U S A. 2005;102:2430-5. https:/ / doi.org/ 10.1073/pnas.0409608102

21. Köndgen S, Schenk S, Pauli G, Boesch C, Leendertz FH. Noninvasive monitoring of respiratory viruses in wild chimpanzees. EcoHealth. 2010;7:332-41. https://doi.org/ 10.1007/s10393-010-0340-z

22. Scully EJ, Basnet S, Wrangham RW, Muller MN, Otali E, Hyeroba D, et al. Lethal respiratory disease associated with human rhinovirus C in wild chimpanzees, Uganda, 2013. Emerg Infect Dis. 2018;24:267-74. https:/ / doi.org/10.3201/ eid2402.170778

23. Shi J, Wen Z, Zhong G, Yang H, Wang C, Huang B, et al. Susceptibility of ferrets, cats, dogs, and other domesticated animals to SARS-coronavirus 2. Science. 2020;368:1016-20. https://doi.org/10.1126/science.abb7015

24. Schlottau K, Rissmann M, Graaf A, Schön J, Sehl J, Wylezich C, et al. Experimental transmission studies of SARS-CoV-2 in fruit bats, ferrets, pigs and chickens. Lancet Microbe. 2020;1:e218-25. https:/ /doi.org/10.1016/ S2666-5247(20)30089-6
25. Wang Q, Vlasova AN, Kenney SP, Saif LJ. Emerging and re-emerging coronaviruses in pigs. Curr Opin Virol. 2019;34:39-49. https:// doi.org/10.1016/j.coviro.2018.12.001

26. Lee C. Porcine epidemic diarrhea virus: An emerging and re-emerging epizootic swine virus. Virol J. 2015;12:193. https:/ / doi.org/10.1186/s12985-015-0421-2

27. Zhou P, Fan H, Lan T, Yang X-L, Shi W-F, Zhang W, et al. Fatal swine acute diarrhoea syndrome caused by an HKU2-related coronavirus of bat origin. Nature. 2018;556:255-8. https:/ / doi.org/10.1038/s41586-018-0010-9

28. Amer HM. Bovine-like coronaviruses in domestic and wild ruminants. Anim Health Res Rev. 2018;19:113-24. https://doi.org/10.1017/S1466252318000117

29. Vijgen L, Keyaerts E, Lemey P, Maes P, Van Reeth K, Nauwynck H, et al. Evolutionary history of the closely related group 2 coronaviruses: porcine hemagglutinating encephalomyelitis virus, bovine coronavirus, and human coronavirus OC43. J Virol. 2006;80:7270-4. https://doi.org/ 10.1128/JVI.02675-05

30. Chen W, Yan M, Yang L, Ding B, He B, Wang Y, et al. SARS-associated coronavirus transmitted from human to pig. Emerg Infect Dis. 2005;11:446-8. https://doi.org/10.3201/ eid1103.040824

31. Oreshkova N, Molenaar R-J, Vreman S, Harders F, Oude Munnink BB, Hakze-van der Honing RW, et al. SARS-CoV-2 infection in farmed minks, the Netherlands, April and May 2020. Euro Surveill. 2020;25:2001005. https://doi.org/10.2807/1560-7917.ES.2020.25.23.2001005

32. World Organisation for Animal Health. COVID 19 portal events in animals; 2020 [cited 2020 Jul 13]. : https:/ / www. oie.int/en/scientific-expertise/specific-information-andrecommendations/questions-and-answers-on-2019novelcoronavirus/events-in-animals

33. Oude Munnink BB, Sikkema RS, Nieuwenhuijse DF, Molenaar RJ, Munger E, Molenkamp R, et al. Transmission of SARS-CoV-2 on mink farms between humans and mink and back to humans. Science. 2021;371:172-7. https:/ / doi.org/ 10.1126/science.abe5901

34. Centers for Disease Control and Prevention. Healthy pets, healthy people, 2020 [cited $2020 \mathrm{Jul}$ 13]. https:/ / www.cdc. gov/healthypets/index.html

35. American Veterinary Medical Association. Pet ownership and demographics sourcebook. Schaumburg (IL): The Association; 2018.

36. Smith K, Boxrud D, Leano F, Snider C, Braden C, Montgomery S, et al.; Centers for Disease Control and Prevention (CDC). Outbreak of multidrug-resistant Salmonella typhimurium associated with rodents purchased at retail pet stores - United States, December 2003October 2004. MMWR Morb Mortal Wkly Rep. 2005; 54:429-33.

37. Hampson K, Coudeville L, Lembo T, Sambo M, Kieffer A, Attlan M, et al.; Global Alliance for Rabies Control Partners for Rabies Prevention. Estimating the global burden of endemic canine rabies. PLoS Negl Trop Dis. 2015;9:e003709. https://doi.org/10.1371/journal.pntd.0003709

38. Stull JW, Brophy J, Weese JS. Reducing the risk of petassociated zoonotic infections. CMAJ. 2015;187:736-43. https://doi.org/10.1503/cmaj.141020

39. Erles K, Toomey C, Brooks HW, Brownlie J. Detection of a group 2 coronavirus in dogs with canine infectious respiratory disease. Virology. 2003;310:216-23. https:/ / doi.org/10.1016/S0042-6822(03)00160-0

40. Erles K, Brownlie J. Canine respiratory coronavirus: an emerging pathogen in the canine infectious respiratory disease complex. Vet Clin North Am Small Anim Pract. 
2008;38:815-25, viii. https://doi.org/10.1016/ j.cvsm.2008.02.008

41. Erles K, Shiu K-B, Brownlie J. Isolation and sequence analysis of canine respiratory coronavirus. Virus Res. 2007 124:78-87. https:// doi.org/10.1016/j.virusres.2006. 10.004

42. Licitra BN, Duhamel GE, Whittaker GR. Canine enteric coronaviruses: emerging viral pathogens with distinct recombinant spike proteins. Viruses. 2014;6:3363-76. https:/ / doi.org/10.3390/v6083363

43. Buonavoglia C, Decaro N, Martella V, Elia G, Campolo M, Desario C, et al. Canine coronavirus highly pathogenic for dogs. Emerg Infect Dis. 2006;12:492-4. https://doi.org/ 10.3201/eid1203.050839

44. Pratelli A. Genetic evolution of canine coronavirus and recent advances in prophylaxis. Vet Res. 2006;37:191-200. https://doi.org/10.1051/vetres:2005053

45. Martina BE, Haagmans BL, Kuiken T, Fouchier RA, Rimmelzwaan GF, Van Amerongen G, et al. Virology: SARS virus infection of cats and ferrets. Nature. 2003;425:915. https:/ / doi.org/10.1038/425915a

46. US Department of Agriculture. Cases of SARS-CoV-2 in animals in the United States, 2020 [cited 2020 Dec 20]. https://www.aphis.usda.gov/aphis/ourfocus/ animalhealth/sa one health/sars-cov-2-animals-us

47. Kim Y-I, Kim S-G, Kim S-M, Kim E-H, Park S-J, Yu K-M, et al. Infection and rapid transmission of SARS-CoV-2 in ferrets. Cell Host Microbe. 2020;27:704-709.e2. https:// doi.org/10.1016/j.chom.2020.03.023

48. Halfmann PJ, Hatta M, Chiba S, Maemura T, Fan S, Takeda M, et al. Transmission of SARS-CoV-2 in domestic cats. N Engl J Med. 2020;383:592-4. https:/ / doi.org/10.1056/NEJMc2013400

49. Centers for Disease Control and Prevention. Toolkit: One Health approach to address companion animals with SARS-CoV-2, 2020 [cited 2020 Dec 20]. https:/ / www.cdc. gov/coronavirus/2019-ncov/animals/toolkit.html

50. Lorusso A, Calistri P, Mercante MT, Monaco F, Portanti O, Marcacci M, et al. A “One-Health" approach for diagnosis and molecular characterization of SARS-CoV-2 in Italy. One Health. 2020;10:100135. https:/ / doi.org/10.1016/ j.onehlt.2020.100135

Address for correspondence: Ria R. Ghai, Centers for Disease Control and Prevention, 1600 Clifton Rd NE, Mailstop H16-5, Atlanta, GA 30329-4027, USA; email: ofu9@cdc.gov

\section{The Public Health Image Library (PHIL)}

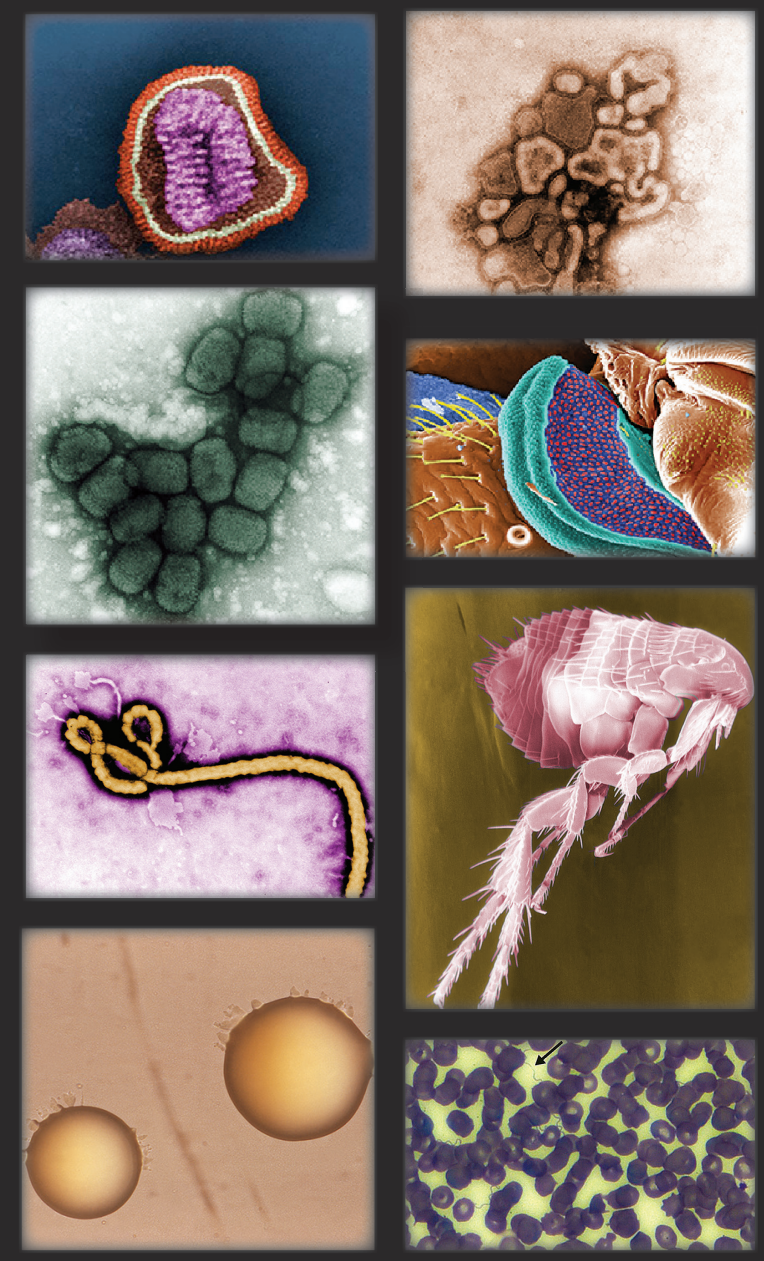

The Public Health Image Library (PHIL), Centers for Disease Control and Prevention, contains thousands of public health-related images, including high-resolution (print quality) photographs, illustrations, and videos.

PHIL collections illustrate current events and articles, supply visual content for health promotion brochures, document the effects of disease, and enhance instructional media.

PHIL images, accessible to PC and Macintosh users, are in the public domain and available without charge.

Visit PHIL at: http: / / phil.cdc.gov/phil 